\title{
Induksi Rimpang Mikro Kaempferia parviflora secara In Vitro dengan Penambahan BAP dan Sukrosa
}

\author{
Application of BAP and Sucrose in the In Vitro Micro Rhizome Induction of \\ Kaempferia parviflora
}

Lefin Kafindra ${ }^{1}$, Nurul Khumaida ${ }^{{ }^{*}}$, dan Sintho Wahyuning Ardie ${ }^{1}$

Diterima 12 Desember 2014/Disetujui 3 Maret 2015

\begin{abstract}
Kaempferia parviflora is a medicinal plant that contains secondary metabolites and effective in alleviating some diseases. Rapid multiplication of $\underline{K}$. parviflora through its rhizome is hampered by the long period needed to produce the rhizome. The objectives of this research were to obtain the best sucrose concentration and to determine the best BAP concentration in the in vitro micro rhizome induction of $\underline{K}$. parviflora. The experiment was arranged in a randomized complete block design with two factors and three replications. The first factor was BAP concentration, consisted of three levels i.e. 0,2 , and $4 \mathrm{mg} \mathrm{L^{-1 }}$. The second factor was sucrose concentration, consisted of four levels i.e. 0, 30, 60, and $90 \mathrm{~g} \mathrm{~L}^{-1}$. Data obtained were analyzed by F-test, followed by DMRT (Duncan Multiple Range Test) at 5\% significant level. Sucrose concentration significantly affected the number of shoots and plantlets fresh weight. The results showed that $\underline{K}$. parviflora could form micro rhizome in vitro, as indicated by similar anatomical structure compared to the rhizome produced in vivo. $\underline{K}$. parviflora cultured in MS medium containing $90 \mathrm{~g} \mathrm{~L}^{-1}$ sucrose without BAP had the highest number of micro rhizome at 8 weeks after culture.
\end{abstract}

Keywords: health, black galingale, traditional medicine

\begin{abstract}
ABSTRAK
Kaempferia parviflora merupakan tanaman obat yang mengandung metabolit sekunder dan berkhasiat untuk mengobati berbagai macam penyakit. Perbanyakan $K$. parviflora menggunakan rimpang terkendala oleh lamanya waktu untuk memproduksi rimpang di lapang, yaitu mencapai 8 bulan setelah tanam. Tujuan penelitian ini ialah memperoleh konsentrasi sukrosa terbaik dan konsentrasi BAP terbaik dalam induksi rimpang mikro $K$. parviflora. Percobaan ini disusun berdasarkan rancangan kelompok lengkap teracak dengan dua faktor dan tiga ulangan. Faktor pertama adalah konsentrasi BAP dengan 3 taraf, yaitu 0 , 2, dan $4 \mathrm{mg} \mathrm{L}^{-1}$. Faktor kedua adalah konsentrasi sukrosa dengan 4 taraf, yaitu $0,30,60$, dan $90 \mathrm{~g} \mathrm{~L}^{-1}$. Data yang diperoleh dianalisis menggunakan uji $\mathrm{F}$ dan apabila berpengaruh nyata, maka dilanjutkan dengan uji lanjut DMRT (Duncan Multiple Range Test) pada taraf $\alpha=5 \%$. Hasil penelitian menunjukkan bahwa K. parviflora dapat membentuk rimpang mikro in vitro. Hal tersebut ditunjukkan oleh struktur anatomi rimpang mikro yang serupa dengan rimpang in vivo. K. parviflora yang dikulturkan pada media MS yang mengandung $90 \mathrm{~g} \mathrm{~L}^{-1}$ sukrosa tanpa BAP memiliki jumlah rimpang mikro tertinggi pada $8 \mathrm{MSP}$.
\end{abstract}

Kata kunci: kesehatan, kencur hitam, obat tradisional

\section{PENDAHULUAN}

Tanaman obat merupakan salah satu tanaman yang penting di Indonesia, karena masyarakat Indonesia banyak memanfaatkannya sebagai ramuan obat tradisional. Angka impor total tanaman obat pada tahun 2012 menunjukkan 24352.81 ton, sedangkan ekspor

\footnotetext{
${ }^{1}$ Departemen Agronomi dan Hortikultura, Fakultas Pertanian, Institut Pertanian Bogor

(Bogor Agricultural University), Jl. Meranti, Kampus IPB Darmaga, Bogor 16680, Indonesia

Telp.\&Faks. 62-251-8629353. *Email korespondensi: nkhumaida@yahoo.com 
3466.22 ton dengan nilai sebesar US\$ 18040 581 dan US\$ 7469935 (Ditjen Hortikultura, 2012). Bentuk ekspor pada umumnya berupa bahan-bahan mentah, seperti tanaman kering, bahan-bahan ekstrak, dan sebagian kecil produk jadi (INATRIMS, 2014). Permintaan yang cukup tinggi terhadap tanaman obat menunjukkan bahwa pengem-bangan komoditas tersebut memiliki peluang pasar yang cukup besar untuk Indonesia. Produksi tanaman obat Indonesia perlu ditingkatkan sejalan dengan permintaan yang cukup tinggi tersebut.

Famili Zingiberaceae memiliki berbagai manfaat bagi masyarakat seperti, obat batuk, rematik, masuk angin, bumbu masak, dan sebagainya. Tanaman Kaempferia parviflora termasuk dalam famili Zingiberaceae yang berasal dari Thailand dan dikenal dengan sebutan "krachai dum", banyak digunakan sebagai obat tradisional penambah energi (Putiyanan et al., 2008). Penelitian menunjukkan bahwa ekstrak rimpang tanaman tersebut mengandung bahan bioaktif seperti antioksidan (Vichitphan et al., 2007), anti depresi (Wattanathorn et al., 2007), anti halusinasi (Tewtrakul dan Subhadirasakul, 2008) dan menghambat aktivitas Helicobacter pylori (Chaichanawongsaroj et al., 2010). Tanaman tersebut banyak digunakan sebagai obat dan kegiatan spiritual oleh masyarakat Thailand (Picheansoonthon dan Koonterm, 2008). Tanaman ini banyak digunakan sebagai ramuan untuk menambah energi, menyeimbangkan tekanan darah serta mengurangi sakit perut di daerah asalnya yaitu Provinsi Loei (Trisomboon, 2009).

Penelitian tim IPB sebelumnya menunjukkan bahwa $K$. parviflora mampu beradaptasi di Indonesia khususnya wilayah Bogor dan sekitarnya sehingga tanaman tersebut berpotensi untuk dikembangkan. Pengembangan secara luas memerlukan bahan tanam yang bermutu. Bahan tanam untuk perbanyakan di lapangan diperoleh dari hasil panen rimpang pertanaman musim sebelumnya. Waktu yang diperlukan untuk memperoleh rimpang yaitu 8 bulan setelah tanam berdasarkan penelitian Zulfa (2012). Penelitian Karim (2013) juga menunjukkan bahwa $K$. parviflora baru dapat bertunas kembali pada 50 sampai 55 hari setelah panen. Oleh karena itu, pendekatan penelitian berupa induksi rimpang mikro $K$. parviflora secara in vitro dengan penambahan BAP dan sukrosa perlu dilakukan untuk menyediakan bahan tanam yang bermutu.

Penambahan karbohidrat diperlukan dalam pengumbian secara in vitro karena tanaman tidak melakukan fotosintesis (Ahmad et al., 2007). Sumber karbohidrat dapat bermacam-macam, salah satunya yaitu sukrosa yang sering digunakan sebagai bahan tambahan dalam kultur jaringan. Penambahan sukrosa (246 mM) pada embrio somatik jeruk keprok Batu 55 mampu meningkatkan terbentuknya planlet lebih banyak dengan ukuran lebih tinggi dibandingkan dengan sukrosa rendah (Widoretno et al., 2013). TDZ mampu mempercepat inisiasi kalus lili (Kurniati et al., 2012) penambahan BAP $13.32 \mu \mathrm{M}$ pada media MS mampu mempercepat waktu bertunas anthurium Wave of Love (Khumaida et al., 2012) Tujuan digunakannya sukrosa yaitu untuk menginisiasi terbentuknya rimpang. Inisiasi rimpang yang optimum dapat terjadi apabila planlet tidak lagi melakukan pertumbuhan secara vegetatif, dalam hal tersebut yaitu pertambahan tunas. Pemberian sukrosa sebesar 6\% mampu menghasilkan umbi tanaman daun dewa (Hartanto et al., 2010). Perlakuan penambahan konsentrasi sukrosa sebesar 30 sampai $80 \mathrm{~g} \mathrm{~L}^{-1}$ mampu menginduksi umbi mikro kentang (Ratna, 2010). Penambahan BAP dan sukrosa mampu menginduksi terbentuknya umbi mikro pada jahe (Rahmawati et al., 2004). Hasil beberapa penelitian tersebut menunjukkan bahwa penambahan BAP dan sukrosa diperlukan untuk menginisiasi terbentuknya rimpang mikro.

Tujuan umum penelitian ini adalah untuk mempelajari induksi rimpang mikro Kaempferia parviflora secara in vitro dan mendapatkan komposisi media yang optimum. Tujuan khusus penelitian ini ialah mengetahui pengaruh konsentrasi BAP dan sukrosa serta interaksinya terhadap pembentukan rimpang mikro K. parviflora.

\section{METODE PENELITIAN}

Penelitian dilaksanakan di Laboratorium Kultur Jaringan 3 dan Laboratorium Mikro-teknik, Departemen Agronomi dan Horti-kultura, IPB. Pelaksanaan penelitian dimulai 18 Maret sampai 23 Agustus 2014. Bahan yang digunakan yaitu eksplan $K$. parviflora dengan umur 1 bulan 
setelah sub kultur. Media dasar yang digunakan yaitu MS0 serta zat pengatur tumbuh (ZPT) berupa BAP dan Sukrosa dengan berbagai taraf. Botol kultur yang akan digunakan, pinset, pisau, gunting, dan cawan petri disterilkan dalam autoklaf selama 60 menit pada suhu $121{ }^{\circ} \mathrm{C}$ dengan tekanan 17.5 psi (pounds per square inch). Kegiatan penanaman dilakukan di dalam laminar air flow cabinet.

Rancangan percobaan yang digunakan dalam penelitian adalah rancangan kelompok lengkap teracak (RKLT). Rancangan perlakuan disusun secara faktorial dengan dua faktor perlakuan. Faktor pertama adalah konsentrasi BAP dengan 3 taraf konsentrasi yaitu 0, 2 dan $4 \mathrm{mg} \mathrm{L}{ }^{-1}$. Faktor yang kedua adalah konsentrasi sukrosa dengan 4 taraf konsentrasi yaitu $0,30,60$, dan $90 \mathrm{~g} \mathrm{~L}^{-1}$. Terdapat 12 Kombinasi perlakuan dengan 3 ulangan sehingga diperoleh 36 satuan percobaan, setiap unit terdiri atas 3 botol, setiap botol terdiri atas 1 tunas. Kelompok dalam penelitian tersebut yaitu waktu penanaman.

Data hasil pengamatan dianalisis dengan menggunakan uji $\mathrm{F}$, apabila terdapat pengaruh yang nyata, maka dilanjutkan dengan uji lanjut DMRT (Duncan Multiple Range Test) pada taraf $\alpha=5 \%$. Pengolahan data dilakukan dengan program Statistical Analysis System (SAS).

Pengamatan dilakukan sebelum dan sesudah perlakuan induksi rimpang mikro. Peubah yang diamati sebelum perlakuan adalah tinggi planlet dan jumlah daun per planlet. Peubah setelah perlakuan yaitu jumlah daun total per planlet, tinggi planlet, jumlah tunas per botol, jumlah akar per botol, jumlah kontaminasi, serta pada akhir pengamatan dilakukan pengamatan morfologi rimpang, bobot basah keseluruhan, bobot kering sampel, pengamatan mikroskopis pada bagian rimpang mikro, daun planlet, batang planlet, serta dibandingkan dengan hasil mikroskopis tanaman yang ada di lapang.

Prosedur pengamatan preparat basah dimulai dengan menyiapkan potongan daun, akar, batang \pm 1 sampai $2 \mathrm{~cm}$ kemudian meletakkannya di atas gelas obyek. Langkah selanjutnya ialah meneteskan air secukupnya di gelas obyek agar sampel tidak kering. Hasil pengamatan selanjutnya difoto menggunakan kamera dengan fokus makro tanpa menggunakan skala. Mikroskop yang digunakan pada pengamatan yaitu mikroskop elektrik (Mulyono, 2014).

\section{HASIL DAN PEMBAHASAN}

Hasil sidik ragam (Tabel 1) menunjukkan bahwa sukrosa berpengaruh sangat nyata terhadap jumlah tunas pada 2 MSP. Sukrosa menunjukkan pengaruh nyata terhadap bobot basah planlet 10 MSP. Analisis terhadap jumlah rimpang menunjukkan bahwa terdapat pengaruh yang sangat nyata pada perlakuan BAP dan nyata pada perlakuan sukrosa dan interaksinya pada 8 MSP. Tinggi planlet menunjukkan pengaruh yang tidak nyata untuk setiap minggu dan semua kombinasi perlakuan, hal tersebut dapat disebabkan oleh planlet yang mengalami etiolasi. Tempat yang gelap merupakan faktor yang dapat me-nyebabkan planlet mengalami etiolasi. Hasil analisis mengenai jumlah daun juga tidak menunjukkan pengaruh yang nyata untuk semua perlakuan dan minggu. Jumlah akar, bobot kering planlet, bobot basah tajuk, bobot rimpang tidak dipengaruhi oleh perlakuan baik pada 8 MSP maupun 10 MSP.

Pertambahan tunas pada 2 MSP menunjukkan hasil yang berbeda nyata pada media perlakuan sukrosa, hal tersebut menunjukkan bahwa planlet baru bereaksi terhadap media perlakuan yang diberikan berupa sukrosa pada 2 MSP. Pertambahan tunas berhubungan erat dengan banyaknya caloncalon rimpang yang akan dihasilkan dari planlet tersebut, semakin banyak jumlah tunas yang dihasilkan diduga semakin banyak pula rimpang yang akan diperoleh selanjutnya.

Penyimpanan cadangan makanan akan terjadi apabila fase vegetatif telah selesai, sehingga akan dimulainya fase generatif, dalam hal tersebut yakni induksi rimpang mikro yang akan terjadi. Berdasarkan hal tersebut, planlet yang digunakan harus dalam kondisi telah selesai atau akan selesai fase vegetatifnya agar dapat berlanjut pada fase berikutnya yaitu generatif, yang nantinya akan menginisiasi terbentuknya rimpang mikro pada planlet tersebut, sehingga induksi rimpang mikro berhasil dilakukan. 
J. Hort. Indonesia 6(1): 54-63. April 2015.

Tabel 1. Rekapitulasi sidik ragam berbagai variabel pengamatan induksi rimpang mikro K. parviflora

\begin{tabular}{|c|c|c|c|c|}
\hline \multirow[b]{2}{*}{ Variabel } & \multicolumn{3}{|c|}{ F-hitung } & \multirow[b]{2}{*}{$\mathrm{KK}(\%)$} \\
\hline & BAP & Sukrosa & $\begin{array}{c}\text { Interaksi } \\
\text { BAP Sukrosa }\end{array}$ & \\
\hline \multicolumn{5}{|l|}{ Tinggi Planlet } \\
\hline $1 \mathrm{MSP}$ & $0.019^{\mathrm{tn}}$ & $2.246^{\mathrm{tn}}$ & $1.046^{\mathrm{tn}}$ & 14.08 \\
\hline $2 \mathrm{MSP}$ & $0.405^{\mathrm{tn}}$ & $1.744^{\text {tn }}$ & $1.316^{\mathrm{tn}}$ & 11.11 \\
\hline $3 \mathrm{MSP}$ & $0.286^{\mathrm{tn}}$ & $1.611^{\mathrm{tn}}$ & $1.075^{\mathrm{tn}}$ & 10.09 \\
\hline $4 \mathrm{MSP}$ & $0.378^{\mathrm{tn}}$ & $0.438^{\mathrm{tn}}$ & $1.357^{\mathrm{tn}}$ & 12.13 \\
\hline $5 \mathrm{MSP}$ & $0.361^{\mathrm{tn}}$ & $0.324^{\text {tn }}$ & $0.914^{\mathrm{tn}}$ & 10.89 \\
\hline $6 \mathrm{MSP}$ & $0.173^{\mathrm{tn}}$ & $0.184^{\text {th }}$ & $0.581^{\mathrm{tn}}$ & 9.97 \\
\hline $7 \mathrm{MSP}$ & $0.104^{\mathrm{tn}}$ & $0.150^{\text {th }}$ & $0.539^{\mathrm{tn}}$ & 10.75 \\
\hline $8 \mathrm{MSP}$ & $0.056^{\mathrm{tn}}$ & $0.190^{\text {th }}$ & $0.530^{\mathrm{tn}}$ & 10.35 \\
\hline \multicolumn{5}{|l|}{ Jumlah Daun } \\
\hline $1 \mathrm{MSP}$ & $1.083^{\mathrm{tn}}$ & $0.148^{\mathrm{tn}}$ & $0.120^{\mathrm{tn}}$ & $10.57^{\operatorname{tr} 2}$ \\
\hline 2 MSP & $0.583^{\text {tn }}$ & $0.101^{\text {tn }}$ & $0.101^{\mathrm{tn}}$ & $10.17^{\text {tr2 }}$ \\
\hline 3 MSP & $0.527^{\text {th }}$ & $0.250^{\mathrm{tn}}$ & $0.194^{\mathrm{tn}}$ & $10.99^{\mathrm{tr} 2}$ \\
\hline 4 MSP & $0.354^{\text {tn }}$ & $0.215^{\text {tn }}$ & $0.268^{\mathrm{tn}}$ & $12.57^{\mathrm{tr} 2}$ \\
\hline 5 MSP & $0.193^{\text {th }}$ & $1.043^{\text {tn }}$ & $0.450^{\mathrm{tn}}$ & $11.80^{\mathrm{tr} 2}$ \\
\hline $6 \mathrm{MSP}$ & $0.616^{\mathrm{tn}}$ & $0.984^{\text {tn }}$ & $0.998^{\mathrm{tn}}$ & $13.92^{\operatorname{tr} 2}$ \\
\hline 7 MSP & $0.203^{\text {tn }}$ & $1.060^{\mathrm{tn}}$ & $0.989^{\mathrm{tn}}$ & $19.09^{\operatorname{tr}}$ \\
\hline 8 MSP & $0.282^{\text {tn }}$ & $0.710^{\text {tn }}$ & $0.917^{\mathrm{tn}}$ & $12.70^{\operatorname{tr} 2}$ \\
\hline \multicolumn{5}{|l|}{ Jumlah Tunas } \\
\hline $1 \mathrm{MSP}$ & $0.083^{\mathrm{tn}}$ & $0.101^{\mathrm{tn}}$ & $0.268^{\mathrm{tn}}$ & 17.21 \\
\hline $2 \mathrm{MSP}$ & $0.583^{\mathrm{tn}}$ & 1.259 ** & $0.287^{\mathrm{tn}}$ & $12.91^{\text {tr }}$ \\
\hline $3 \mathrm{MSP}$ & $1.083^{\mathrm{tn}}$ & $0.740^{\text {tn }}$ & $0.824^{\mathrm{tn}}$ & $11.01^{\mathrm{tr}}$ \\
\hline 4 MSP & $0.369^{\mathrm{tn}}$ & $0.901^{\text {tn }}$ & $0.509^{\mathrm{tn}}$ & $14.60^{\operatorname{tr} 2}$ \\
\hline 5 MSP & $0.966^{\mathrm{tn}}$ & $0.249^{\text {th }}$ & $0.635^{\mathrm{tn}}$ & $15.20^{\operatorname{tr}}$ \\
\hline $6 \mathrm{MSP}$ & $2.617^{\mathrm{tn}}$ & $0.552^{\text {tn }}$ & $1.593^{\mathrm{tn}}$ & $14.82^{\text {tr }}$ \\
\hline 7 MSP & $2.433^{\mathrm{tn}}$ & $0.051^{\text {tn }}$ & $0.669^{\mathrm{tn}}$ & $18.51^{\mathrm{tr}}$ \\
\hline 8 MSP & $2.023^{\mathrm{tn}}$ & $1.213^{\mathrm{tn}}$ & $2.037^{\mathrm{tn}}$ & $13.14^{\mathrm{tr} 2}$ \\
\hline \multicolumn{5}{|l|}{ Jumlah Akar } \\
\hline $6 \mathrm{MSP}$ & $9.156^{\mathrm{tn}}$ & $5.806^{\mathrm{tn}}$ & $37.957^{\text {tn }}$ & $14.82^{\text {tr }}$ \\
\hline $7 \mathrm{MSP}$ & $53.957^{\text {tn }}$ & $1.964^{\text {tn }}$ & $55.041^{\text {tn }}$ & $11.86^{\text {tr }}$ \\
\hline $8 \mathrm{MSP}$ & $50.638^{\text {th }}$ & $4.044^{\text {tn }}$ & $43.575^{\text {tn }}$ & $12.95^{\text {tr }}$ \\
\hline \multicolumn{5}{|c|}{ Bobot Basah Planlet } \\
\hline $8 \mathrm{MSP}$ & $0.126^{\mathrm{tn}}$ & $0.042^{\text {tn }}$ & $0.559^{\mathrm{tn}}$ & $12.82^{\operatorname{tr} 3}$ \\
\hline $10 \mathrm{MSP}$ & $0.518^{\mathrm{tn}}$ & $1.540^{*}$ & $0.537^{\mathrm{tn}}$ & $18.44^{\mathrm{tr}}$ \\
\hline \multicolumn{5}{|c|}{ Bobot Kering Planlet } \\
\hline $8 \mathrm{MSP}$ & $0.034^{\mathrm{tn}}$ & $0.002^{\text {tn }}$ & $0.012^{\text {tn }}$ & $1.85^{\mathrm{tr} 3}$ \\
\hline 10 MSP & $0.004^{\mathrm{tn}}$ & $0.025^{\mathrm{tn}}$ & $0.013^{\mathrm{tn}}$ & $5.28^{\text {tr2 }}$ \\
\hline \multicolumn{5}{|l|}{ Bobot Basah Tajuk } \\
\hline 8 MSP & $0.061^{\mathrm{tn}}$ & $0.039^{\mathrm{tn}}$ & $0.109^{\mathrm{tn}}$ & $14.41^{\mathrm{tr} 2}$ \\
\hline $10 \mathrm{MSP}$ & $0.297^{\mathrm{tn}}$ & $0.207^{\text {tn }}$ & $0.251^{\mathrm{tn}}$ & $10.05^{\mathrm{tr} 2}$ \\
\hline \multicolumn{5}{|l|}{ Bobot Rimpang } \\
\hline $8 \mathrm{MSP}$ & $0.029^{\mathrm{tn}}$ & $0.033^{\text {tn }}$ & $0.223^{\text {tn }}$ & $17.32^{\operatorname{tr} 2}$ \\
\hline $10 \mathrm{MSP}$ & $0.378^{\text {tn }}$ & $0.642^{\text {tn }}$ & $0.130^{\mathrm{tn}}$ & $13.46^{\mathrm{tr} 2}$ \\
\hline \multicolumn{5}{|l|}{ Jumlah Rimpang } \\
\hline 8 MSP & $0.025 * *$ & $0.012 *$ & $0.009 *$ & $10.58^{\mathrm{tr} 2}$ \\
\hline
\end{tabular}

Keterangan: MSP: minggu setelah perlakuan **: sangat nyata pada taraf $1 \%$. *: nyata pada taraf $5 \%$. tn: tidak nyata. ${ }^{\mathrm{tr}}$ : hasil transformasi $\log (x+1),{ }^{\mathrm{t} 2}$ : hasil transformasi $\log (x+2), \mathrm{KK}(\%)$ : koefisien keragaman.

Hasil pengamatan terhadap tinggi planlet seperti yang tersaji pada gambar 1 menunjukkan kurva yang sigmoid, serta terlihat bahwa secara umum sejak 5 MSP planlet sudah berhenti pertambahan tingginya. Penambahan tinggi terhenti dapat disebabkan oleh sudah selesainya fase vegetatif planlet, dan dimulainya fase generatif pada planlet tersebut. Pengamatan terhadap jumlah tunas menunjukkan kurva yang tidak berpola, namun secara umum planlet telah tidak mengalami per-tambahan tunas pada 6 MSP, meskipun terdapat perlakuan BAP $3 \mathrm{mg} \mathrm{L}^{-1}$ dan sukrosa $0 \mathrm{~g} \mathrm{~L}^{-1}$ yang terlihat signifikan pertambahan hingga minggu ke 8 seperti yang tersaji pada gambar 1, hal tersebut tidak cukup untuk 
membuat perlakuan berpengaruh nyata pada uji statistik.

Hasil pengamatan pada peubah jumlah daun menunjukkan bahwa planlet tidak mengalami pertambahan daun sejak 1 MSP hingga 4 MSP. Planlet mengalami pertambahan daun pada 5 MSP dan secara umum mulai berhenti bertambah pada 6 MSP seperti yang tersaji pada Gambar 2.
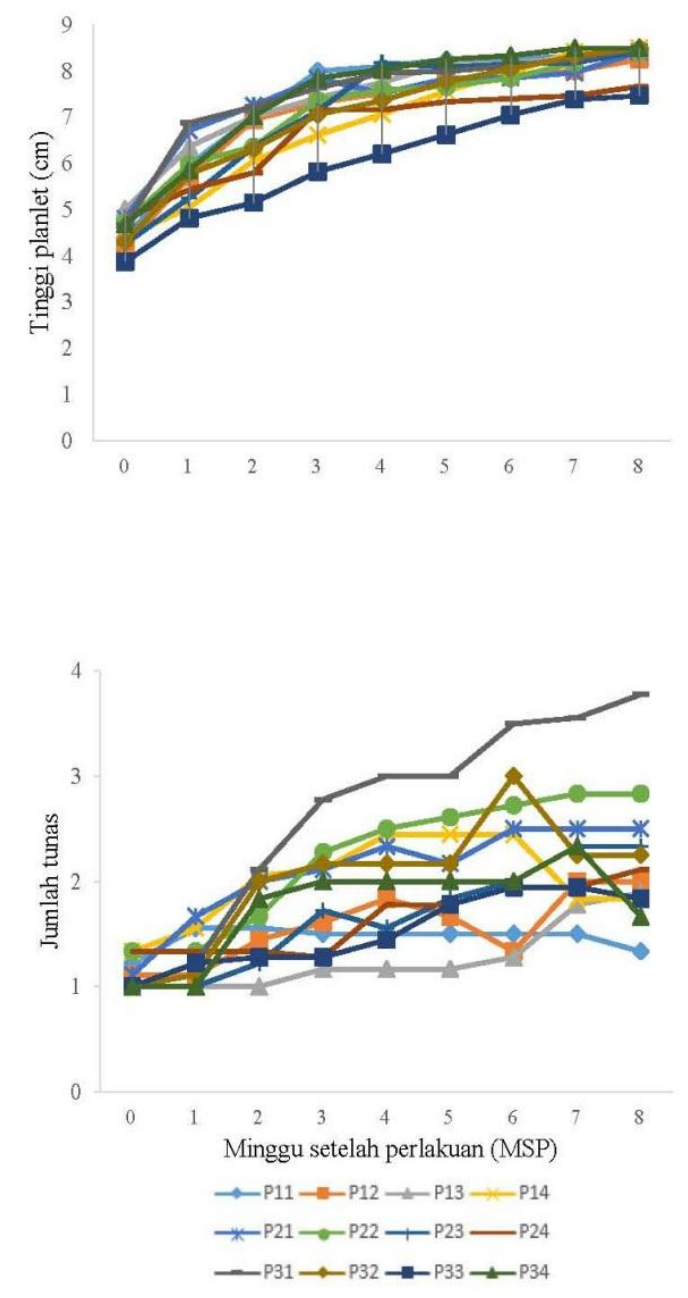

Keterangan: P11: BAP 0 Sukrosa 0, P12: BAP 0 Sukrosa 30, P13: BAP 0 Sukrosa 60, P14: BAP 0 Sukrosa 90, P21: BAP 2 Sukrosa 0, P22: BAP 2 Sukrosa 30, P23: BAP 2 Sukrosa 60, P24: BAP 2 Sukrosa 90, P31: BAP 3 Sukrosa 0, P32: BAP 3 Sukrosa 30, P33: BAP 3 Sukrosa 60, P34: BAP 3 Sukrosa 90, BAP (mg L $\left.{ }^{-1}\right)$, Sukrosa $\left(\mathrm{g} \mathrm{L}^{-1}\right)$.

Gambar 1. Pertambahan tinggi dan jumlah tunas planlet Kaempferia parviflora
Data jumlah daun (Tabel 2) menunjukkan jumlah daun untuk semua perlakuan berkisar antara 1 sampai 3 helai. Jumlah daun paling banyak, dengan standar deviasi yang kecil terdapat pada kombinasi $90 \mathrm{~g} \mathrm{~L}^{-1}$ sukrosa tanpa BAP. Jumlah tunas untuk semua perlakuan secara umum berkisar antara 1 sampai 2. Jumlah tunas paling banyak ditunjukkan oleh perlakuan $2 \mathrm{mg} \mathrm{L}^{-1}$ BAP tanpa sukrosa, meskipun tidak berbeda nyata. Jumlah akar hasil pengamatan menunjukkan nilai yang berkisar antara 12 sampai 24 . Jumlah tunas terbanyak ditunjukkan oleh perlakuan $2 \mathrm{mg} \mathrm{L^{-1 }}$ BAP tanpa sukrosa, meskipun tidak berbeda nyata dengan perlakuan lain. Jumlah rimpang menunjukkan nilai yang berkisar antara 0 sampai 1 . Perlakuan yang menghasilkan rimpang paling banyak terdapat pada $90 \mathrm{~g} \mathrm{~L}^{-1}$ sukrosa tanpa BAP, kombinasi $30 \mathrm{~g} \mathrm{~L}^{-1}$ sukrosa dan $2 \mathrm{mg} \mathrm{L}^{-1}$ BAP, serta $30 \mathrm{~g} \mathrm{~L}^{-1}$ sukrosa dan $4 \mathrm{mg} \mathrm{L}^{-1}$ BAP.

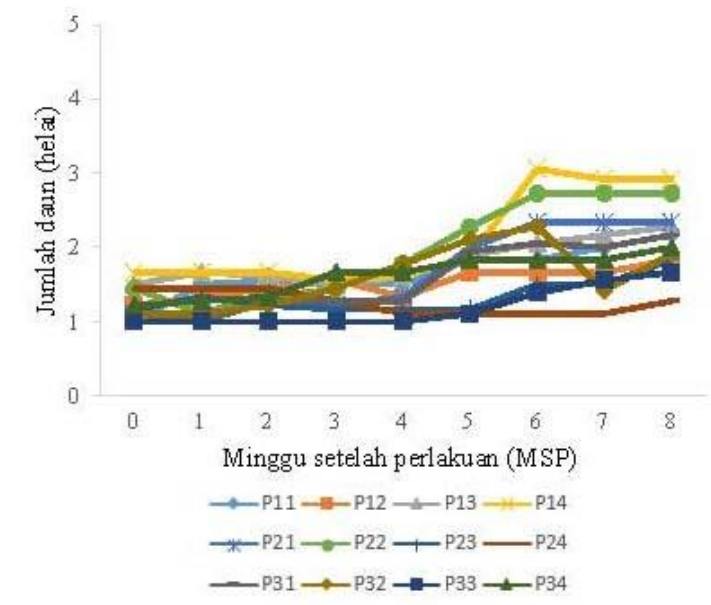

Keterangan: P11: BAP 0 Sukrosa 0, P12: BAP 0 Sukrosa 30, P13: BAP 0 Sukrosa 60, P14: BAP 0 Sukrosa 90, P21: BAP 2 Sukrosa 0, P22: BAP 2 Sukrosa 30, P23: BAP 2 Sukrosa 60, P24: BAP 2 Sukrosa 90, P31: BAP 3 Sukrosa 0, P32: BAP 3 Sukrosa 30, P33: BAP 3 Sukrosa 60, P34: BAP 3 Sukrosa 90, BAP $\left(\mathrm{mg} \mathrm{L}^{-1}\right)$, Sukrosa $\left(\mathrm{g} \mathrm{L}^{-1}\right)$.

Gambar 2. Pertambahan jumlah daun planlet Kaempferia parviflora 
Tabel 2. Jumlah daun, tunas, akar, serta rimpang mikro planlet $K$. parviflora pada 8 MSP

\begin{tabular}{|c|c|c|c|c|}
\hline \multirow[b]{2}{*}{$\mathrm{BAP}(\mathrm{mg} \mathrm{L}-1)$} & \multicolumn{4}{|c|}{ Sukrosa $\left(\mathrm{g} \mathrm{L}^{-1}\right)$} \\
\hline & 0 & 30 & 60 & 90 \\
\hline & \multicolumn{4}{|c|}{....Jumlah Daun... } \\
\hline 0 & $2 \pm 1.3$ & $2 \pm 0.3$ & $2 \pm 1.2$ & $3 \pm 0.8$ \\
\hline 2 & $2 \pm 0.5$ & $3 \pm 1.2$ & $2 \pm 1.0$ & $1 \pm 0.3$ \\
\hline \multirow[t]{2}{*}{4} & $2 \pm 1.0$ & $2 \pm 0.8$ & $2 \pm 0.6$ & $2 \pm 0.5$ \\
\hline & & \multicolumn{2}{|c|}{......Jumlah Tunas.......... } & \\
\hline 0 & $1 \pm 0.3$ & $2 \pm 1.4$ & $2 \pm 0.2$ & $2 \pm 0.2$ \\
\hline 2 & $3 \pm 0.7$ & $3 \pm 1.0$ & $2 \pm 1.0$ & $2 \pm 0.8$ \\
\hline \multirow[t]{2}{*}{4} & $4 \pm 0.7$ & $2 \pm 1.8$ & $2 \pm 1.0$ & $2 \pm 0.8$ \\
\hline & & \multicolumn{2}{|c|}{.......Jumlah Akar........... } & ....... \\
\hline 0 & $12 \pm 5.3$ & $19 \pm 4.6$ & $20 \pm 9.6$ & $19 \pm 7.1$ \\
\hline 2 & $24 \pm 13.0$ & $24 \pm 14.3$ & $17 \pm 2.1$ & $15 \pm 6.9$ \\
\hline \multirow[t]{2}{*}{4} & $18 \pm 8.9$ & $18 \pm 5.1$ & $14 \pm 7.4$ & $19 \pm 5.7$ \\
\hline & & \multicolumn{2}{|c|}{.....Jumlah Rimpang.......... } & \\
\hline 0 & $0.3 \pm 0.6$ & $0.7 \pm 0.6$ & $0.7 \pm 0.6$ & $1.3 \pm 0.6$ \\
\hline 2 & $1 \pm 0$ & $1.3 \pm 0.6$ & $1 \pm 0$ & $1 \pm 0$ \\
\hline 4 & $1 \pm 0$ & $1.3 \pm 0.6$ & $0.7 \pm 0.6$ & $1 \pm 0$ \\
\hline
\end{tabular}

Ketererangan: MSP: minggu setelah perlakuan

Hasil pengamatan terhadap variabel mikroskopis rimpang baik secara in vitro maupun in vivo mendukung hasil yang meyakinkan bahwa induksi rimpang mikro telah berhasil dilakukan. Struktur sel (Gambar 3) menunjukkan bahwa terdapat kesamaan antara hasil induksi rimpang secara in vitro dan in vivo. Irisan melintang menunjukkan anatomi yang sama antara rimpang yang dihasilkan dari lapang dan rimpang yang dihasilkan secara kultur in vitro. Rimpang in vivo (Gambar 3) merupakan hasil dari planlet yang diperbanyak secara in vitro dan ditanam di lapang, hasil menunjukkan bahwa tanaman yang berasal dari perbanyakan secara in vitro mampu menghasilkan rimpang.

Struktur bagian yang sama menjadi indikasi khusus bahwa rimpang yang dihasilkan baik secara in vitro maupun in vivo merupakan rimpang yang sama, yakni yang dapat digunakan sebagai bahan perbanyakan. Pengembangan usaha bisnis di bidang hortikultura khususnya dari famili Zingiberaceae dapat diatasi dengan dilakukannya penyiapan bahan perbanyakan melalui induksi rimpang mikro secara in vitro. Pengembangan obat-obatan yang berasal dari bahan-bahan rimpang dapat dilakukan penyediaan bahan yang lebih cepat serta memiliki mutu yang seragam apabila digunakan persiapan menggunakan metode induksi rimpang mikro.
Hasil analisis data pengaruh sukrosa terhadap jumlah tunas $K$. parviflora (Tabel 3) menunjukkan bahwa pemberian sukrosa $0 \mathrm{~g}$ $\mathrm{L}^{-1}$ dan sukrosa $90 \mathrm{~g} \mathrm{~L}^{-1}$ memiliki pengaruh yang nyata jika dibandingkan dengan perlakuan $60 \mathrm{~g} \mathrm{~L}^{-1}$ terhadap pembentukan jumlah tunas. Hasil analisis menunjukkan juga pemberian sukrosa $0 \mathrm{~g} \mathrm{~L}^{-1}$ dan $90 \mathrm{~g} \mathrm{~L}^{-1}$ tidak berbeda nyata terhadap perlakuan $30 \mathrm{~g} \mathrm{~L}^{-1}$. Hasil penelitian ini sejalan dengan penelitian Lyla (2011) yang melaporkan bahwa dengan taraf sukrosa 5\% mampu menghasilkan tunas optimum untuk perbanyakan mata tunas kunyit putih. Induksi rimpang mikro berhasil dilakukan pada sukrosa $90 \mathrm{~g} \mathrm{~L}^{-1}$, hal tersebut sejalan dengan hasil penelitian Rahmawati et al. (2004) yang melaporkan bahwa jahe dapat diinduksi rimpang mikro sukrosa tanpa BAP. Taraf yang menguntungkan berdasarkan hasil pengamatan menunjukkan taraf sukrosa $90 \mathrm{~g}$ $\mathrm{L}^{-1}$ tanpa BAP, hal tersebut akan berpengaruh terhadap jumlah biaya yang dikeluarkan untuk bahan perbanyakan di lapang.

Hasil analisis data pengaruh sukrosa (Tabel 3) menunjukkan bahwa pemberian sukrosa 30, 60, $90 \mathrm{~g} \mathrm{~L}^{-1}$ memiliki pengaruh yang nyata apabila dibandingkan dengan perlakuan tanpa sukrosa, terhadap bobot basah planlet yang dihasilkan. Pemberian sukrosa 30 g $\mathrm{L}^{-1}$ memiliki nilai yang paling tinggi dibandingkan semua perlakuan, meskipun tidak berbeda nyata terhadap perlakuan 60 dan 
90 g L L $\mathrm{L}^{-1}$ sukrosa yang diberikan. Hasil penelitian terhadap bobot basah planlet tersebut sejalan dengan penelitian Rahmawati et al. (2004) yang menunjukkan bahwa konsentrasi sukrosa berpengaruh nyata terhadap bobot basah planlet pada taraf 30 sampai $50 \mathrm{~g} \mathrm{~L}^{-1}$ sukrosa yang diaplikasikan.
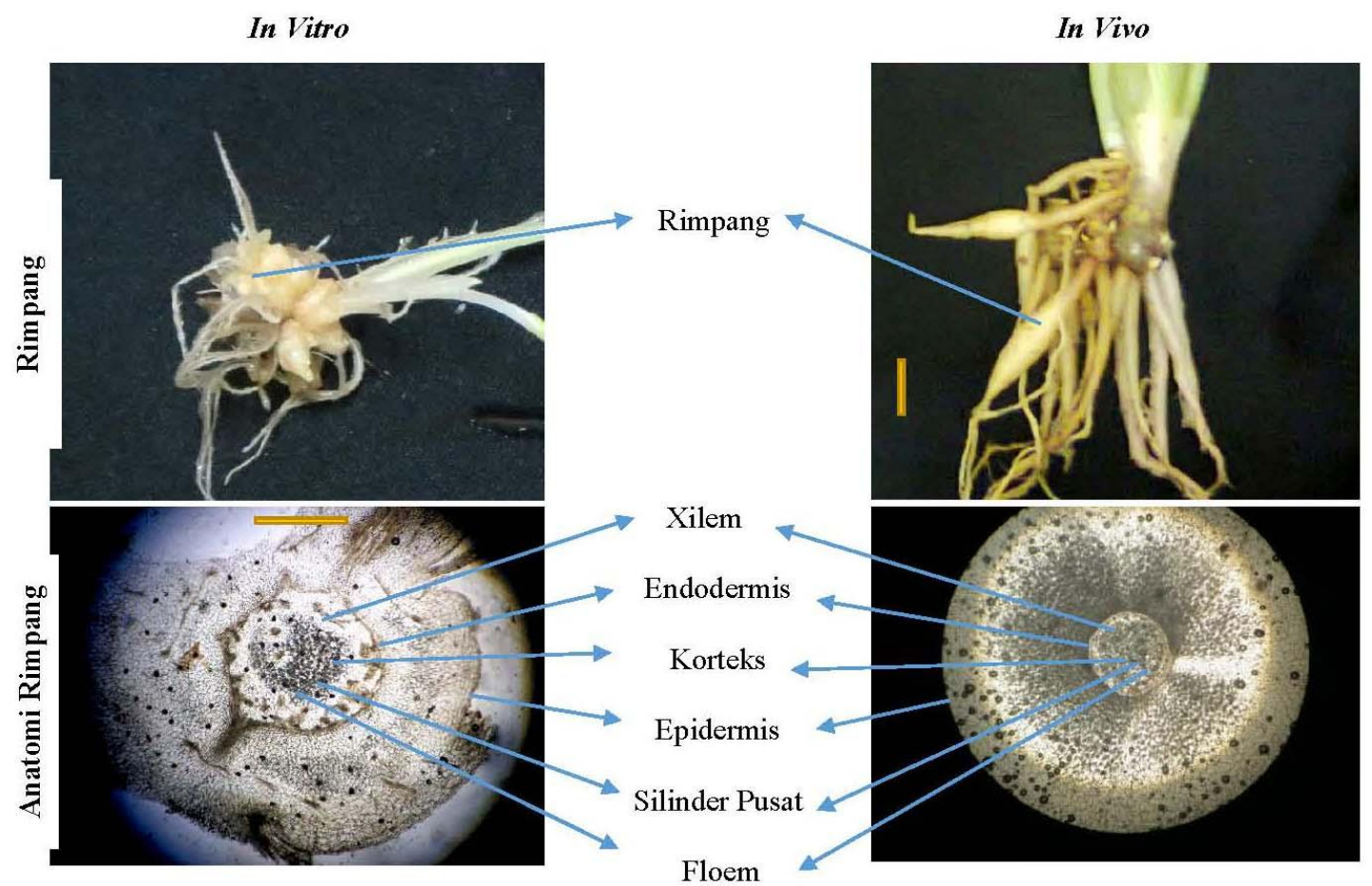

Keterangan: $\square$ : Skala $1 \mathrm{Cm}$

Gambar 3. Keragaan rimpang in vitro dan in vivo Kaempferia parviflora

Tabel 3. Pengaruh sukrosa terhadap jumlah tunas 2 MSP dan bobot basah planlet 10 MSP K. Parviflora

\begin{tabular}{ccccc}
\hline \multirow{2}{*}{ Variabel } & \multicolumn{4}{c}{ Konsentrasi Sukrosa $\left(\mathrm{g} \mathrm{L}^{-1}\right)$} \\
\cline { 2 - 5 } & 0 & 30 & 60 & 90 \\
\hline $\begin{array}{c}\text { Jumlah } \\
\text { Tunas }\end{array}$ & $2.0 \mathrm{a}$ & $1.7 \mathrm{ab}$ & $1.1 \mathrm{~b}$ & $1.9 \mathrm{a}$ \\
$\begin{array}{c}\text { Bobot Basah } \\
\text { Planlet }\end{array}$ & $1.1 \mathrm{~b}$ & $2.0 \mathrm{a}$ & $1.9 \mathrm{a}$ & $2.0 \mathrm{a}$ \\
\hline Keterangan: Angka yang diikuti oleh huruf kecil pada \\
$\begin{array}{l}\text { kolom yang sama dan angka yang diikuti } \\
\text { oleh huruf besar pada baris yang sama } \\
\text { menunjukkan tidak berbeda nyata pada } \\
\text { taraf 5\%. }\end{array}$
\end{tabular}

Hasil analisis data interaksi BAP dan sukrosa (Tabel 4) menunjukkan bahwa pemberian BAP $0 \mathrm{mg} \mathrm{L}^{-1}$ dan sukrosa $90 \mathrm{~g} \mathrm{~L}^{-1}$ memiliki pengaruh yang nyata terhadap jumlah rimpang mikro yang dihasilkan. Hasil interaksi lainnya menunjukkan hasil yang tidak signifikan antar kombinasi media yang digunakan. Pemberian sukrosa $90 \mathrm{~g} \mathrm{~L}^{-1}$ dan 0 $\mathrm{mg} \mathrm{L}^{-1}$ BAP dapat digunakan sebagai rekomendasi dalam penelitian sejenis mengenai induksi rimpang mikro. Pemberian BAP 0,2 , dan $4 \mathrm{mg} \mathrm{L}^{-1}$ tidak memiliki pengaruh yang nyata terhadap jumlah rimpang mikro yang dihasilkan. Penggunaan kombinasi tersebut lebih dipilih karena ditinjau dari segi ekonomi lebih menguntungkan dari sudut pandang bisnis, untuk tujuan penyediaan bahan tanam secara cepat dan bermutu.

Tabel 4. Interaksi BAP dan sukrosa pada peubah jumlah rimpang mikro planlet Kaempferia parviflora 8 MSP

\begin{tabular}{ccccc}
\hline \multirow{2}{*}{$\begin{array}{c}\text { BAP } \\
\left(\mathrm{mg} \mathrm{L}^{-1}\right)\end{array}$} & 0 & \multicolumn{4}{c}{ Sukrosa $\left(\mathrm{g} \mathrm{L}^{-1}\right)$} \\
\cline { 2 - 5 } & $0.3 \mathrm{aB}$ & $0.7 \mathrm{aAB}$ & $0.7 \mathrm{aAB}$ & $1.3 \mathrm{aA}$ \\
2 & $1.0 \mathrm{aA}$ & $1.3 \mathrm{aA}$ & $1.0 \mathrm{aA}$ & $1.0 \mathrm{aA}$ \\
4 & $1.0 \mathrm{aA}$ & $1.3 \mathrm{aA}$ & $0.7 \mathrm{aA}$ & $1.0 \mathrm{aA}$ \\
\hline
\end{tabular}

Keterangan: Angka yang diikuti oleh huruf kecil pada kolom yang sama dan angka yang diikuti oleh huruf besar pada baris yang sama menunjukkan tidak berbeda nyata pada taraf $5 \%$. 
Tabel 5. Hasil analisis korelasi beberapa variabel pengamatan Kaempferia parviflora pada 8 MSP

\begin{tabular}{clcccllll}
\hline Peubah & JT & \multicolumn{1}{c}{ JD } & \multicolumn{1}{c}{ TS } & JA8 & BB8 & BK8 & BBA & BBT \\
\hline \multirow{2}{*}{ JD } & 0.317 & & & & & & & \\
& 0.078 & & & & & & & \\
JT & 0.114 & 0.142 & & & & & \\
& 0.534 & 0.437 & & & & & \\
JA & 0.244 & 0.003 & 0.275 & & & & \\
& 0.178 & 0.986 & 0.128 & & & & \\
BB & 0.091 & 0.201 & 0.204 & 0.094 & & & \\
& 0.627 & 0.278 & 0.271 & 0.614 & & & \\
BK & 0.179 & -0.112 & -0.026 & -0.248 & 0.456 & & \\
& 0.335 & 0.548 & 0.889 & 0.179 & $0.006^{* *}$ & & \\
BBA & 0.068 & 0.098 & 0.203 & 0.124 & 0.954 & 0.505 & \\
& 0.716 & 0.602 & 0.274 & 0.506 & $0.000^{* *}$ & $0.002^{* *}$ & & \\
BBT & 0.108 & 0.308 & 0.181 & 0.045 & 0.824 & 0.338 & 0.726 & \\
& 0.561 & 0.092 & 0.331 & 0.812 & $0.000^{* *}$ & $0.047^{*}$ & $0.000^{* *}$ & \\
JR8 & 0.154 & 0.150 & 0.255 & 0.341 & 0.078 & -0.174 & 0.098 & 0.003 \\
& 0.484 & 0.494 & 0.240 & 0.112 & 0.706 & 0.395 & 0.633 & 0.987 \\
\hline
\end{tabular}

Keterangan: **: sangat nyata pada taraf $1 \%$, *: nyata pada taraf $5 \%$. JD : Jumlah daun per planlet, JT: Jumlah tunas per planlet, JA: Jumlah akar per planlet, TS: Jumlah tunas, BB: Bobot basah per planlet, BK: Bobot kering per planlet, BBA: Bobot basah akar per planlet, BBT: Bobot basah tajuk per planlet, JR: Jumlah rimpang per planlet

Korelasi adalah hubungan antar peubah dari faktor yang diamati. Korelasi antar peubah dari beberapa peubah yang diamati disajikan pada Tabel 6. Hasil analisis menunjukkan bahwa bobot basah per planlet pada 8 MSP berkorelasi sangat nyata dengan bobot kering per planlet 8 MSP dan bobot basah tajuk per planlet, hal tersebut menjelaskan bahwa meningkatnya bobot basah dapat meningkatkan pula bobot kering dan bobot tajuk basah. Korelasi positif sangat nyata juga ditunjukkan oleh bobot kering per planlet terhadap bobot basah akar per planlet, hal tersebut menunjukkan bahwa meningkatnya bobot basah akar dapat meningkatkan bobot kering planlet. Bobot basah akar berkorelasi positif sangat nyata terhadap bobot kering tajuk, meningkatnya bobot basah akar dapat meningkatkan bobot tajuk planlet.

Bobot basah tajuk juga berkorelasi positif nyata terhadap bobot kering planlet, dengan demikian meningkatnya bobot basah tajuk dapat meningkatkan bobot basah planlet. Hasil analisis korelasi tersebut menunjukkan bahwa jumlah rimpang mikro tidak dipengaruhi oleh semua faktor seperti jumlah tunas, jumlah daun, jumlah akar, bobot basah, serta bobot kering. Jumlah rimpang diduga dapat berkorelasi positif dengan waktu yang diperlukan untuk menginisiasi rimpang mikro hal tersebut sejalan dengan konsep induksi rimpang di lapang yang menunjukkan hasil yang lebih banyak rimpang yang dihasilkan apabila waktu yang tersedia untuk diinduksi bertambah.

\section{KESIMPULAN}

Pemberian perlakuan BAP dengan taraf 0 sampai $4 \mathrm{mg} \mathrm{L}^{-1}$ tidak menunjukkan pengaruh yang nyata terhadap induksi rimpang mikro Kaempferia parviflora. Sukrosa yang diberikan berpengaruh nyata terhadap pembentukan jumlah tunas 2 MSP dan bobot basah planlet 10 MSP. K. parviflora dapat membentuk rimpang mikro secara in vitro, hal tersebut karena struktur anatomi rimpang yang sama dengan struktur anatomi rimpang in vivo. $K$. parviflora yang dikulturkan pada media MS yang mengandung $90 \mathrm{~g} \mathrm{~L}^{-1}$ sukrosa tanpa BAP memiliki jumlah rimpang mikro tertinggi pada 8 MSP.

\section{DAFTAR PUSTAKA}

Ahmad, T., N.A. Abbasi, I.A. Hafiz, A. Ali. 2007. Comparison of sucrose and sorbitol as main carbon energy sources in micropropagation of peach rootstock gf-677. Pak J Bot. 39(4): 1269-1275. 
Chaichanawongsaroj, N., S. Amonyingcharoen, E. Saifah, Y. Poovorawan. 2010. The effect of Kaempferia parviflora on antiinternalization activity of Helicobacter pylori to HEp-2 cells. Afr J Biotechnol. 9: 4796-4801.

Ditjen Hortikultura. 2012. Volume Impor dan Ekspor Tanaman Obat 2012. http:// hortikultura.deptan.go.id/index.php?vie $\mathrm{w}=$ article \&catid $=57$ :eksporimpor\&id= 338:volume-nilai-impordan-ekspor-obat th2012\&format=pdf\&option=com content\&Itemid $=474 . \quad[21 \quad$ Desember 2013].

Hartanto, D., S.A. Aziz, D. Dinarti. 2010. Induksi umbi tanaman daun dewa (Gynura pseudochina (Lour.) DC) secara in vitro dengan perlakuan sukrosa dan daminozide. J Agron Indonesia. 38(2): 144-149.

[INATRIMS] Indonesia Technical Regulations Informations Management System. 2014. Tujuan Utama Ekspor Produk Tanaman Obat Indonesia. Kementerian Perdagangan Republik Indonesia

http://inatrims.kemendag.go.id/id/ product/detail/medicinal-herbs_16. [27 Januari 2014].

Karim, M.A. 2013. Pematahan dormansi rimpang Kaempferia parviflora Wall. Ex. Baker. Skripsi. Institut Pertanian Bogor. Bogor.

Khumaida, N., C.H.S. Riyanti, D. Sukma. 2012. Induksi multiplikasi tunas anthurium Wave of Love (Anthurium plowmanii) secara in vitro. J. Hort Indonesia. 3(1): 1-9.

Kurniati, R., A. Purwito, G.A. Wattimena, B. Marwoto, Supenti. 2012. Induksi kalus tiga kultivar lili dari petal bunga pada beberapa jenis media. J. Hort Indonesia. 3(1): 17-23.

Lyla, N.A. 2011. Pengaruh kadar sukrosa dalam medium MS (Mushasige \& Skoog) [tesis]. Universitas Dipenogoro. Semarang.
Mulyono, J. 2014. Pengantar Laboratorium Mikroteknik. Institut Pertanian Bogor. Bogor.

Nugroho, N.A. 1998. Manfaat dan Prospek Pengembangan Kunyit. Ed ke-1. PT. Trubus Agriwidya. Ungaran.

Picheansoonthon, C., S. Koonterm. 2008. Notes on the genus Kaempferia L. (Zingiberaceae) in Thailand. $\mathrm{J}$ Thai Traditional Alternative Medicine. 6(1):1-21.

Putiyanan, S., S. Chansakaow, A. Phrutivorapongkul, W. Charoensup. 2008. Standard pharmacognostic characteristic of some Thai Herrbal medicine. CMU J Nat Sci.7(2): 239-255.

Rahmawati, M., S.A. Aziz, D. Dinarty, D.R. Sastra. 2004. Pengaruh BAP dan sukrosa terhadap perbanyakan jahe empirit (Zingiber officinale Rose var. Amarun). Bul Agron. 32(3): 37-43.

Ratna, D. 2010. Induksi umbi mikro kentang udara (Dioscorea bulbifera L.) dengan perlakuan beberapa konsentrasi sukrosa. Skripsi. Universitas Andalas. Padang.

Samanhudi, A. Yunus, A.T. Sakya, R. Hartati. 2002. Pengaruh paklobutrazol dan aspirin dalam pembentukan umbi mikro kentang (Solanum tuberosum L.). J Agrosains. 5(1):19-28.

Tewtrakul, S., S. Subhadirasakul. 2008. Effects of compounds from Kaempferia parviflora on nitric oxide. prostaglandin E2 and tumornecrosis factor alpha productions in RAW 264.7 macrophage cells. J Etnopharmacol. 120: 81-84.

Trisomboon, H. 2009. Kaempferia parviflora. a Thai herbal plant. neither promote reproductive function nor increase libido via male hormone. Thai J Physiological Sci. 21(2):83-86.

Vichitphan, S., K. Vichitphan, P. Sirikhansaeng. 2007. Flavonoid content and antioxidant activity of krachai-dum (Kaempferia parviflora) wine. KMITL Sci Tech J. 7: 97-105. 
Wattanathorn, J., P. Pangpookiew, K. Sripanidkulchai, S. Muchimapura, B. Sripanidkuchai. 2007. Evaluation of the anxiolytic and antidepressant effect of alcoholic extract of Kaempferia parviflora in aged rats. Am J Agri. Biol Sci. 2: 9498.

Widoretno, W., C. Martasari, F.D. Nirmala. 2013. Pengaruh sukrosa dan fotoperiode terhadap embriogenesis somatik jeruk Keprok Batu 55 (Citrus reticulata Blanco.). J. Hort Indonesia. 4(1): 44-53.

Zulfa, U. 2012. Application of liquid biofertilizer reduced the need of chemical fertilizer in black galingale (Kaempferia parviflora) production. Skripsi. Institut Pertanian Bogor. Bogor. 